\title{
Functional Properties and Nutritional Quality of Some Wild and Edible Bean in Nigeria
}

\author{
O. A. Awoyinka', A. O. Ileola², C. N. Imeoria ${ }^{3}$, S. T. Olumakinde ${ }^{3}$, F. C. Oladele1, \\ M. F. Asaolu ${ }^{2}$ \\ ${ }^{1}$ Department of Medical Biochemistry, College of Medicine, Ekiti State University, Ado Ekiti, Nigeria \\ ${ }^{2}$ Department of Biochemistry, Ekiti State University, Ado Ekiti, Nigeria \\ ${ }^{3}$ Department of Science Laboratory Technology, Ekiti State University, Ado Ekiti, Nigeria \\ Email: olayinka.awoyinka@eksu.edu.ng
}

Received 6 February 2016; accepted 21 February 2016; published 25 February 2016

Copyright (C) 2016 by authors and OALib.

This work is licensed under the Creative Commons Attribution International License (CC BY). http://creativecommons.org/licenses/by/4.0/

(c) (i) Open Access

\section{Abstract}

In this study on bean, four wild types were compared with the edible for their functional and nutritional characteristics in unprocessed and malted form. Results obtained in functional properties showed that bulk density was higher in wild types compared to edibles types. Feregede has the least dispersibility compared to all the bean samples. The swelling power of all the wild and edible types was almost the same with the edible bean IT845-2246-4 having the highest value of $26.15 \pm$ 0.02. Pakala had the broadest foaming stability even up to the region of alkaline $\mathrm{pH}$. In proximate compositions, the entire edible bean had more carbohydrate and crude fibre content than the wild types but after malting, there was no significant difference $(P<0.05)$ in the crude fibre content between the edible and the wild type beans. After malting, it was observed that Pakala and edible bean IT99K-573-1-1 had more moisture content with the values $9.2 \pm 0.14$ and $9 \pm 0.15$ respectively. There was no significant difference in the protein content across both the wild and edible bean and ranged between $28.45 \pm 0.012$ and $30.70 \pm 0.014$ while these values were slightly reduced after malting. This study reveals that Mucuna and other types of underutilized wild beansOtili, Feregede, and Pakala are important food sources that can be exploited to mitigate shortage in animal protein and under nutrition facing families in many developing countries particularly in Nigeria.

\section{Keywords}

Wild Beans, Edible Beans, Foaming Capacity, Swelling Capacity, Dispersibility

Subject Areas: Nutrition

How to cite this paper: Awoyinka, O.A., Ileola, A.O., Imeoria, C.N., Olumakinde, S.T., Oladele, F.C. and Asaolu, M.F. (2016) Functional Properties and Nutritional Quality of Some Wild and Edible Bean in Nigeria. Open Access Library Journal, 3: e2411. http://dx.doi.org/10.4236/oalib.1102411 


\section{Introduction}

Beans seeds are rich sources of plant proteins that present a substitute for the scarce animal proteins. Bean seeds consist of array of edible types otherwise known as common bean and non-common wild types otherwise known as non-edible types. Of the many known of this legume specie, few are used extensively today as food [1]-[3]. The edible types are known to be used especially in developing countries as a staple of diet, due to their relatively very low cost, high nutritional value and health benefit [4] [5]. They are also explored more in the developed countries as ingredients primarily to provide a variety of functional properties, including desirable structure, texture, flavour, and colour characteristics in formulated food products [6] [7]. They are widely used in high protein foods including dairy foods, nutritional supplements, meat systems, infant formulas, nutritional beverages, cream soups, sauces and snacks and also as a protein source in milk replacers [8] [9]. In this respect, the edible bean types appear to be the most explored among the beans. Interestingly, utilization of legume protein by the food industry has increased interest in seed protein research.

Mucuna and other types of wild beans [(Sphenostylis stenocarpa Africa Yam bean; (Otili), Cajanus cajan Pigeon Pea; (Feregede), Phaseolus lunatus Lima bean/Butter bean; (Pakala)] presented in this report are grossly underutilized tropical legume. Information on Mucuna and the other wild bean being study in this present work is scarce. They are grown in tropical countries as a green manure/cover crop [10] [11]. Mucuna especially is known to be rich in protein (23\% - 35\%) and has a nutritional quality comparable to other pulses like soybean, rice bean and lima bean [12] [13]. It has good potential as a cheap and alternate source of protein while its foaming, gelation and electrophoretic characteristics, protein concentrates have been well studied by Adebowale et al. [14]. However, there have been reports in Nigeria that, the wild bean-African yam bean, pigeon bean and lima bean are popular legumes consumed in many communities [15]-[17]. Chemical composition of these grain legumes were shown to contain high quantities of proteins, amino acids, fiber and minerals [18] [19]. Their high intake has been associated with reducing the risk of developing diabetes, hypertension, animal's cancer and hypercholesterolemia [20]. Their hard-to-cook phenomenon and the presence of antintutrients have limited their utilisation [13] [21]. At present in Nigeria they are usually eaten in cooked form after overnight cooking. In the process, it consumes a lot of fuel and high loss of nutrients. Attempts have been made to improve their utilisation in human diet due to increasing need for cheaper and available plant proteins to meet the increasing demand of the Nigerian populace. For example, reducing cooking time and acceptability have been achieved for pigeon pea through dehulling process [22].

Despite all these aforementioned findings, these wild beans are still considered an orphan crop, with a huge untapped potential for improvement both in quantity and quality of food products. Conversely, the commonly relied source of quality protein which is animal protein is grossly expensive and scarce. Hence the objectives of this study is to compare the functional properties, nutritional quality of selected Nigerian wild type bean with the common edible type and identify the needs for future work on these assumed wild type. Since the need for sustainable development and economic recovery in the developing regions of the world is crucial particularly in the area of access to quality proteinous food.

\section{Materials and Method}

\subsection{Collection of Materials}

The legume (beans) used in this work are of two types; Edible beans and Wild-type beans. The edible types are pure breed from International Institute of Tropical Agriculture (IITA) and the wild-types are gotten from the farmers in Ado-Ekiti.

\section{Physical Characteristic Test}

This is the determination of color, bean classification, and number of bean per $10 \mathrm{~g}$. From each sample, some beans were selected randomly and placed in petri-dish each. The weight of $10 \mathrm{~g}$ of beans was determined by a weighing balance.

\subsection{Functional Properties of the Samples}

\subsubsection{Bulk Densities}

This was determined by the method of Narayana and Nrasinga-Rao [23]. A graduated measuring cylinder was 
filled to $100 \mathrm{ml}$ with the sample. The sample was packed by gently tapping the cylinder on the laboratory bench. Bulk density was recorded as a ratio of weight (g) of sample to volume (ml).

\subsubsection{Dispersibility Test}

The method of Kulkarni et al. [24] was adopted for the dispersibility determination. $10 \mathrm{~g}$ of each flour sample were weighed into a $100 \mathrm{ml}$ measuring cylinder, distilled water was added up to $100 \mathrm{ml}$ volume. The sample was vigorously stirred and allowed to settle for 1hour, the volume of settled particles was recorded and subtracted from 100 to give a difference that is taken as percentage dispersibility.

\subsubsection{Swelling Properties}

Swelling power was determined by the procedure of Takashi and Seib [25]. The sample was first kept in the oven at $44^{\circ} \mathrm{C}$ for 1 hour. $1 \mathrm{~g}$ of flour sample was mixed with $10 \mathrm{ml}$ of distilled water contained in a centrifuge tube. The slurry was stirred, the tube with the slurry was gently lowered into a water bath and held at $70^{\circ} \mathrm{C}$ for 15 minutes with slow but continuous stirring to prevent clumping with its contents. The tube containing the paste was centrifuged at $3000 \times \mathrm{g}$ for 10 minutes then the weight was taken after centrifugation.

\subsubsection{Seed Viability}

This is the rate at which the seeds get sprouted when they are subjected to certain condition. The inner of the petri dish was covered with a cotton wool, the bean seed was put inside and they were sprinkle with water. The petri dish was covered with its lid. This was leave for 3 days to allow sprouting of the seeds.

\subsubsection{Foaming Capacity}

Foaming capacity was determined according to Dipak and Kumar [26]. $2 \mathrm{~g}$ of each sample was whipped with $100 \mathrm{ml}$ of distilled water in the test-tubes at different $\mathrm{pH}$ ranging from $\mathrm{pH} 2-10$ for 5 minutes. The increase in volume on whipping was measured. Foam capacity was expressed as a percentage of the original volume of the liquid. Foam stability was expressed as a percentage of foam volume remaining in relation to initial foam volume at room temperature after 10, 20, 30, 40 and 50 minutes.

\subsubsection{Proximate Analysis}

Associations of Official Analytical Chemist [27], procedure were used to determine the proximate composition of the different vegetable sample.

\subsubsection{Crude Fibre Determination}

Two grams sample was put into $200 \mathrm{ml}$ of $1.25 \%$ of $\mathrm{H}_{2} \mathrm{SO}_{4}$ and boiled for 30 minutes. The solution and content then poured into bucheur funnel equipped with muslin cloth and secured with elastic band. This was allowed to filter and residue washed with hot water to free it from acid. The residue was then put into $200 \mathrm{ml}$ boiling $1.25 \%$ $\mathrm{NaOH}$ and boiled for $30 \mathrm{~min}$, then filtered. It was then washed twice with alcohol the material obtained was washed thrice with petroleum ester. The residue obtained was put in a clean dry crucible and dried in the moisture extraction oven to a constant weight. The dried crucible was removed, cooled and weighed. Then difference of weight (i.e. loss in ignition) is recorded as crucible fibre and expressed in percentage of the original weight.

$$
\text { Percentage crude fibre }=\frac{\mathrm{W} 1-\mathrm{W} 2}{\mathrm{~W} 3} \times 100
$$

where;

$\mathrm{W} 1$ = Weight of sample before incineration;

W2 = Weight of sample after incineration;

W3 = Weight of original sample.

\subsubsection{Fat Content Determination}

Two grams sample was loosely wrapped with a filter paper and put into the thimble which is fitted to a clean round bottom flask, which has been cleaned, dried and weighed. The flask contained $120 \mathrm{ml}$ of petroleum ether. The sample was heated with a heating mantle and allowed to reflux for $5 \mathrm{~h}$. The heating was then stopped and the thimbles with the spent samples kept and later weighed. The difference in weight was received as mass of fat 
and is expressed in percentage of the sample. The percentage oil content is calculated;

$$
\text { Percentage Fat }=\frac{\mathrm{W} 2-\mathrm{W} 1}{\mathrm{~W} 3} \times 100
$$

where

W1 = Weight of the empty extraction flask;

$\mathrm{W} 2$ = Weight of the flask and oil extracted;

W3 $=$ Weight of the sample.

\subsubsection{Ash Content Determination}

Two grams of each of the samples was weighed into crucible, heated in a moisture extraction oven for $3 \mathrm{~h}$ at $100^{\circ} \mathrm{C}$ before being transferred into a muffle furnace until it turned white and free of carbon. The sample was then removed from the furnace, cooled in desiccators to a room temperature and reweighed immediately. The weight of the residue was then calculated as ash content expressed in percentage.

$$
\text { Percentage ash }=\frac{\text { Weight of Ash } \times 100}{\text { Weight of sample }}
$$

\subsubsection{Crude Protein Determination}

The microkjeldahl method described by AOAC [27] was used. Two grams, each of the samples was mixed with $10 \mathrm{ml}$ of concentrated $\mathrm{H}_{2} \mathrm{SO}_{4}$ in a heating tube. One tablet of selenium catalyst was added to the tube and mixture heated inside a fume cupboard. The digest was transferred into a $100 \mathrm{ml}$ volumetric flask and made up with distilled water. Ten milliliter portion of the digest was mixed with equal volume of $45 \% \mathrm{NaOH}$ solution and poured into a kjeldahl distillation apparatus. The mixture was distilled and the distillate collected into $4 \%$ boric acid solution containing 3 drops of zuazaga indicator. A total of $50 \mathrm{ml}$ distillate was collected and titrate as well. The sample was duplicated and the average value taken. The nitrogen content was calculated and multiplied with 6.25 to obtain the crude protein content.

$$
\text { Percentage Nitrogen }=\frac{(100 \times \mathrm{N} \times 14 \times \mathrm{Vf}) \mathrm{T}}{100 \times \mathrm{Va}}
$$

where: $\mathrm{W}=$ Weight of the ample;

$\mathrm{N}=$ Normality of the titrate $(0.1 \mathrm{~N})$;

$\mathrm{vf}=$ Total volume of the digest $=100 \mathrm{ml}$;

$\mathrm{T}$ = Titre value;

$\mathrm{va}=$ Aliquot volume distilled .

\subsubsection{Carbohydrate Content Determination}

The nitrogen free method described by AOAC [27] was used. The carbohydrate is calculated as weight by difference between 100 and the summation of other proximate parameters as Nitrogen Free Extract (NFE).

$$
\text { Percentage carbohydrate }(\mathrm{NFE})=100-(\mathrm{M}+\mathrm{P}+\mathrm{F} 1+\mathrm{F} 2)
$$

where;

$$
\mathrm{M} \text { = moisture; } \mathrm{P} \text { = protein; } \mathrm{F} 1 \text { = fat; } \mathrm{A} \text { = ash; } \mathrm{F} 2 \text { = fibre. }
$$

\section{Results and Discussion}

This report is based on the premise that, a number of functional properties are invariably enhanced during malting. They include ash composition, protein, fat, reconstitution indices, water holding capacities and foaming properties [28]-[31].

The results obtained on the functional parameters (Table 1) being considered in this investigation showed that there were generally marked variations in all the tests carried out. There were correlation in the bulk density across the wild beans and are found between the ranged $80.2 \pm 0.06$ and $83.7 \pm 0.04$ Showing clearly to be denser than the edible types which are found between the ranged $70.70 \pm 0.02$ and $77.77 \pm 0.03$. Table 1 further shows the result on the seed viability test carried out on each sample where Pakala is significantly different with 
Table 1. Result of functional properties of the samples.

\begin{tabular}{ccccc}
\hline Sample & Bulk Densities & Dispersibility & $\begin{array}{c}\text { Swelling } \\
\text { properties }\end{array}$ & Seed viability \\
\hline Otili & $83.70 \pm 0.04$ & $73.7 \pm 0.06$ & $24.8 \pm 0.03$ & $1.53 \pm 0.01$ \\
Feregede & $82.5 \pm 0.05$ & $66.50 \pm 0.03$ & $24.5 \pm 0.02$ & $3.0 \pm 0.01$ \\
Pakala & $80.2 \pm 0.06$ & $72.0 \pm 0.04$ & $24.35 \pm 0.03$ & $5.4 \pm 0.01$ \\
Mucuna & $83.5 \pm 0.04$ & $77.0 \pm 0.03$ & $24.00 \pm 0.04$ & $4.83 \pm 0.01$ \\
IT99K - 573 - -1 & $77.77 \pm 0.03$ & $76.5 \pm 0.05$ & $24.65 \pm 0.03$ & $2.73 \pm 0.03$ \\
IT99K - 573 - $1-1$ & $77.07 \pm 0.02$ & $71.5 \pm 0.03$ & $26.65 \pm 0.03$ & $2.83 \pm 0.02$ \\
IT97K - 499 - 35 & $73.87 \pm 0.03$ & $77.0 \pm 0.06$ & $24.65 \pm 0.04$ & $4.83 \pm 0.03$ \\
IT07K - 243 - $1-10$ & $71.00 \pm 0.04$ & $71.0 \pm 0.04$ & $24.45 \pm 0.02$ & $3.16 \pm 0.02$ \\
IT04K - 333 - 2 & $70.70 \pm 0.02$ & $72.0 \pm 0.05$ & $24.9 \pm 0.01$ & $3.33 \pm 0.01$ \\
IT845 - 2246 - 4 & $74.26 \pm 0.02$ & $70.5 \pm 0.04$ & $26.15 \pm 0.02$ & $3.20 \pm 0.01$ \\
\hline
\end{tabular}

the value $5.4 \pm 0.01$ from the rest of the samples. Water absorption, holding or binding capacity (WAC) may be defined as ability of food material to hold its own and added water during application of forces and heating. Water absorption is due to its dipolar nature so that proteins with more charged amino acids tend to absorb more water than proteins with uncharged amino acids [9] [32]. Low water absorption capacity Feregede compared to others may be attributed to decreased charge on its protein. The swelling power of all the Samples (Wild and Edible types) were almost the same except edible bean IT845-2246-4 with the higher value of $26.15 \pm 0.02$ (Table 1) of swelling power. The result of dispersibility shows Feregede with the least value of $66.50 \%$ compare to other bean which were found to be high and closely related. These observations suggest in exception of Feregedeall the bean samples would have almost the same ability to retain same amount of water for the gelati/nization process, and swell appreciably at same rate [31]. The ability of protein to gel and provide a structure for holding water, flavours, sugars and food ingredients is useful in food applications [33]. However, the sprouting of the seeds which was measured as the seed viability was higher in the wild bean Pakala, followed by $\mathrm{Mu}$ cuna and Edible bean IT97K-499-35. The foaming property of each sample was the foaming stability (Figure 1). At pH 2 (acidic $\mathrm{pH}$ ) Otili showed the highest foaming stability, while Pakala showed the lowest foaming stability. At pH 4 (Acidic $\mathrm{pH}$ ), all the Wild types displayed the highest foaming stability except Feregede with lower foaming stability. Also all the Edible types displayed low foaming. At $\mathrm{pH} 6$ (Acidic $\mathrm{pH}$ ) all the Wild types displayed the highest foaming stability than the edible bean IT99k-573-2-1 competed with Feregede and Mucuna in its foaming stability (Figure 1). At pH 8 the Wild types showed the highest foaming stability Feregede that dropped rapidly in its foaming stability. At pH 10 only Pakala in all the Wild types showed the highest foaming stability while all the Edible types showed the lowest foaming stability except edible bean IT99K-573-2-1. At $\mathrm{pH} 12$ all the wild types also showed the highest foaming stability. The high stability of foam up to alkaline $\mathrm{pH}$ region by the wild bean may be as result of formation of stable molecular layers in the air-water interface that imparts stability, and elasticity to the foams [25] [31]. In food foams, foaming performance depends on the ability of the continuous phase to include air (foam capacity) and also retain it for specific period of time (foam stability) [12].

Table 2 and Table 3 show the results of proximate analysis carried out on the pulverized non-malted dry bean and pulverized malted bean respectively. As shown, in Table 2 the results on the moisture content with the edible bean IT845-2246-4 having the highest value of $8.90 \pm 0.013$ compare to other samples. Both wild and edible beans appreciably had increase in moisture content after malting. After malting it was observed Pakala and edible bean IT99K-573-1-1 had more moisture content with the values $9.2 \pm 0.14$ and $9 \pm 0.15$ respectively (Table 3). Moisture content is an index of water activity of many foods and a factor for a long shelf life since microorganisms that cause spoilage does not thrive in foods having low moisture content [2].

The Edible bean has the higher percentage of crude fibre content than the Wild types but after malting there was no significance difference in the crude fibre content between the edible and the wild type beans. A number 


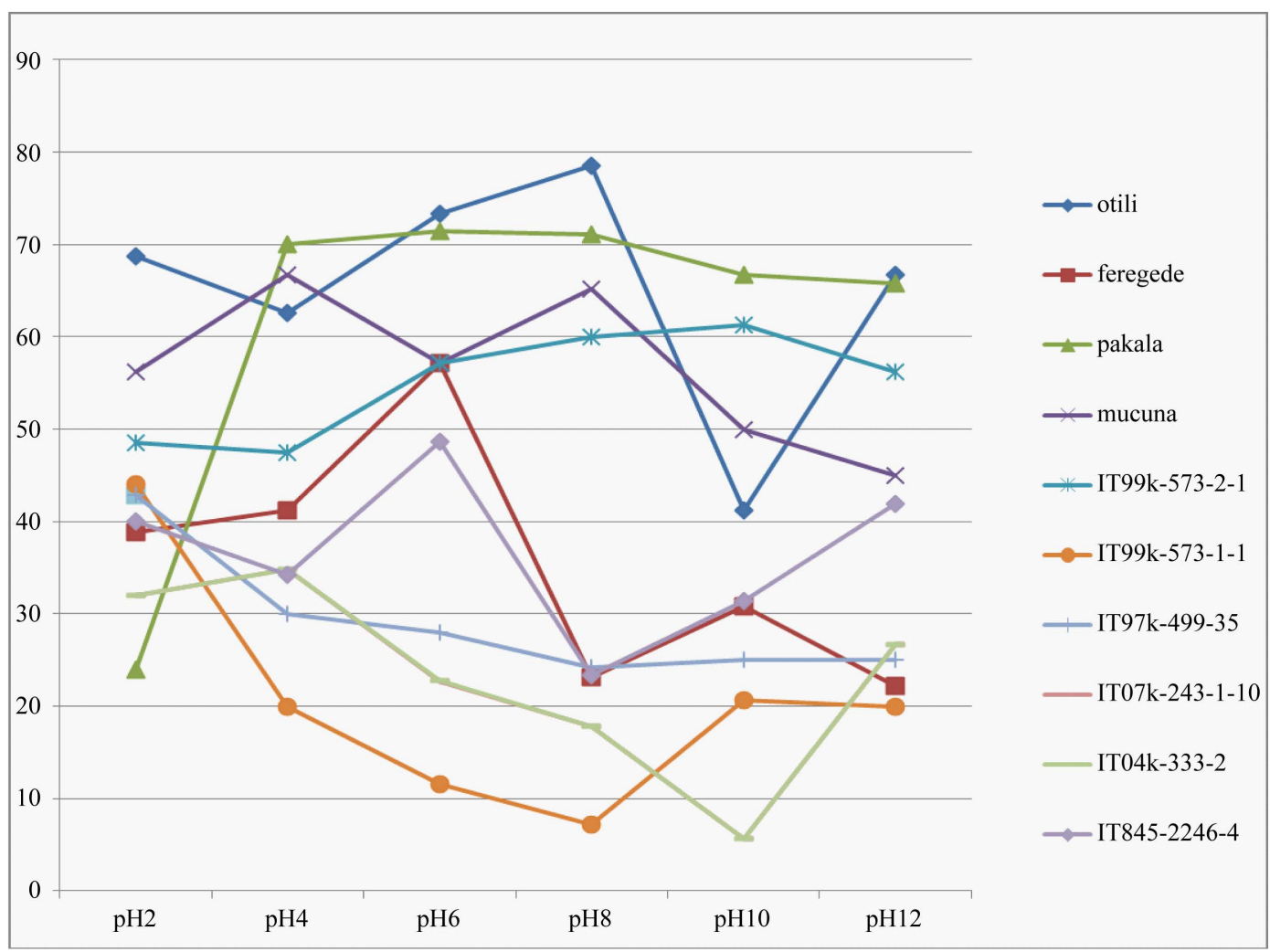

Figure 1. Graph showing the plot of foaming properties of the samples with respect to ph and time (minutes).

Table 2. Result of proximate analysis of pulverized samples.

\begin{tabular}{|c|c|c|c|c|c|c|}
\hline Sample & $\begin{array}{c}\text { Moisture content } \\
\text { (\%) }\end{array}$ & Crude fibre (\%) & Fat content (\%) & Ash content (\%) & Protein content (\%) & $\begin{array}{c}\text { Carbohydrate } \\
\text { (\%) }\end{array}$ \\
\hline Otili & $7.10 \pm 0.013$ & $6.10 \pm 0.018$ & $2.84 \pm 0.011$ & $4.20 \pm 0.012$ & $31.50 \pm 0.012$ & $48.24 \pm 0.017$ \\
\hline Feregede & $6.10 \pm 0.015$ & $7.40 \pm 0.013$ & $2.97 \pm 0.012$ & $3.90 \pm 0.012$ & $29.46 \pm 0.013$ & $50.26 \pm 0.012$ \\
\hline Pakala & $6.90 \pm 0.012$ & $7.90 \pm 0.017$ & $2.95 \pm 0.014$ & $5.10 \pm 0.011$ & $30.09 \pm 0.015$ & $47.15 \pm 0.015$ \\
\hline Mucuna & $8.70 \pm 0.014$ & $7.90 \pm 0.011$ & $2.79 \pm 0.018$ & $3.42 \pm 0.013$ & $30.70 \pm 0.014$ & $46.54 \pm 0.018$ \\
\hline IT99K - 573 - 2 - 1 & $8.10 \pm 0.011$ & $6.80 \pm 0.015$ & $3.00 \pm 0.013$ & $6.90 \pm 0.018$ & $29.10 \pm 0.011$ & $46.00 \pm 0.014$ \\
\hline IT99K - 573 - 1 - 1 & $7.80 \pm 0.013$ & $7.80 \pm 0.012$ & $2.74 \pm 0.019$ & $5.68 \pm 0.012$ & $30.09 \pm 0.018$ & $48.12 \pm 0.011$ \\
\hline IT97K - 499 - 35 & $5.70 \pm 0.014$ & $8.70 \pm 0.018$ & $2.87 \pm 0.017$ & $3.46 \pm 0.011$ & $29.90 \pm 0.013$ & $50.03 \pm 0.014$ \\
\hline IT07K - 243 - 1 - 10 & $5.70 \pm 0.012$ & $8.02 \pm 0.016$ & $2.47 \pm 0.014$ & $4.84 \pm 0.01$ & $28.45 \pm 0.012$ & $50.43 \pm 0.017$ \\
\hline IT04K - 333 - 2 & $7.60 \pm 0.014$ & $9.71 \pm 0.013$ & $3.10 \pm 0.016$ & $3.14 \pm 0.011$ & $28.90 \pm 0.014$ & $47.84 \pm 0.014$ \\
\hline IT845 - 2246 - 4 & $8.90 \pm 0.013$ & $8.61 \pm 0.011$ & $2.91 \pm 0.012$ & $3.89 \pm 0.012$ & $29.98 \pm 0.011$ & $45.54 \pm 0.019$ \\
\hline
\end{tabular}

of studies have indicated that components of plants such as dietary fiber have beneficial effects in lowering blood cholesterol levels. It cleanses the digestive tract, by removing potential carcinogens keeping them away from the cells lining the colon, providing yet another line of protection from colon cancer [34]. Prior to malting the fat content of edible bean IT99K-573-2-1 and IT04K-333-2 were significantly higher than other bean sample with the values $3.00 \pm 0.013$ and $3.10 \pm 0.016$ respectively from other samples (Table 2). However, after malting there was no significant different in all the bean samples (Table 3). Lipid bodies decrease in direct proportion to the lipase content during germination due to the activation of synthesized lipase. Free fatty acids (FFAs) 
Table 3. Result of proximate analysis of malted samples.

\begin{tabular}{ccccccc}
\hline Sample & $\begin{array}{c}\text { Moisture content } \\
(\%)\end{array}$ & Crude fibre (\%) & Fat content (\%) & Ash content (\%) & $\begin{array}{c}\text { Protein content } \\
\text { (\%) }\end{array}$ & $\begin{array}{c}\text { Carbohydrate } \\
\text { (\%) }\end{array}$ \\
\hline Otili & $8.3 \pm 0.02$ & $6.8 \pm 0.045$ & $2.77 \pm 0.01$ & $4.47 \pm 0.01$ & $29.90 \pm 0.01$ & $47.72 \pm 0.02$ \\
Feregede & $7 \pm 0.15$ & $7.67 \pm 0.05$ & $2.94 \pm 0.08$ & $3.35 \pm 0.02$ & $28.80 \pm 0.08$ & $50.16 \pm 0.13$ \\
Pakala & $9.2 \pm 0.14$ & $7.14 \pm 0.06$ & $2.45 \pm 0.01$ & $5.6 \pm 0.08$ & $29.15 \pm 0.01$ & $46.40 \pm 0.15$ \\
Mucuna & $11 \pm 0.02$ & $8.10 \pm 0.02$ & $2.7 \pm 0.02$ & $3.91 \pm 0.51$ & $27.87 \pm 0.01$ & $46.95 \pm 0.4$ \\
IT99K - 573 - 2 - 1 & $8 \pm 0.03$ & $7.8 \pm 0.08$ & $2.94 \pm 0.02$ & $6.92 \pm 0.01$ & $28.10 \pm 0.01$ & $45.41 \pm 0.04$ \\
IT99K - 573 - 1 - 1 & $9 \pm 0.15$ & $8.3 \pm 0.02$ & $2.68 \pm 0.01$ & $5.94 \pm 0.01$ & $27.76 \pm 0.08$ & $45.09 \pm 0.18$ \\
IT97K - 499 - 35 & $6 \pm 0.34$ & $8.7 \pm 0.02$ & $2.61 \pm 0.01$ & $4.81 \pm 0.14$ & $28.10 \pm 0.01$ & $50.58 \pm 0.30$ \\
IT07K - 243 - 1 - 10 & $5.9 \pm 0.03$ & $7.28 \pm 0.02$ & $2.46 \pm 0.02$ & $4.16 \pm .008$ & $27.76 \pm 0.08$ & $52.44 \pm 0.96$ \\
IT04K - 333 - 2 & $7.1 \pm 0.01$ & $8.8 \pm 0.01$ & $2.98 \pm 0.01$ & $3.98 \pm 0.01$ & $28.80 \pm 0.04$ & $48.13 \pm 0.29$ \\
IT845 - 2246 - 4 & $8.7 \pm 0.02$ & $7.9 \pm 0.08$ & $2.91 \pm 0.08$ & $3.87 \pm 0.09$ & $29.10 \pm 0.57$ & $48.19 \pm 0.45$ \\
\hline
\end{tabular}

resulting from its hydrolysis during germination will therefore contribute significantly to the pool of FFAs available for peroxidative reactions which will result in flavour instability (rancidity) of the products [31]. Table 2 also shows the result on the Ash content of the samples, where edible bean IT99K-573-2-1 had the highest value of $6.90 \pm 0.018$ compared to other bean sample even after malting with the value $6.92 \pm 0.01$ from the rest of the samples. This suggests that they all contain almost the same mineral content.

Table 2 further shows the result on the protein content carried out on the samples where sample Otili, Pakala and Mucuna had a significantly values $31.50 \pm 0.012$, $30.09 \pm 0.015$ and $30.70 \pm 0.014$ respectively but with a slight reduction to $29.90 \pm 0.01,28.80 \pm 0.08$ and $29.15 \pm 0.01$ after malting (Table 3 ). The protein content is comparable with those in other legumes [5] [35]-[37]. This shows that the seeds have a great potential in alleviating chronic protein deficiency syndromes that are widespread in developing countries such as Nigeria. Table 2 and Table 3 show the result of carbohydrate content before and after malting the results show Feregede as the only wild bean that compete favourably with other edible beans in carbohydrate content.

\section{Conclusion}

From this study, it can be deduced that the functional properties such as the bulk densities swelling power and dispersibility are high in both the wild and edible type. In the proximate compositions, there was no significant difference in the protein content across both the wild and edible bean, but the edible bean had more carbohydrate and crude fibre content than the wild bean.

\section{Acknowledgements}

The present project was partly funded by Tet Fund Research grant 2015.

\section{References}

[1] Brough, S.H., Azam-Ali, S.N. and Taylor, A.J. (1993) The Potential of Bambara Groundnut (Vigna subterranea) in Vegetable Milk Production and basic Protein Functionality Systems. Food Chemistry, 47, 277-283. http://dx.doi.org/10.1016/0308-8146(93)90161-8

[2] Chinedu, N.S. and Nwinyi, O.C. (2012) Proximate Analysis of Sphenostylis stenocarpa and Voadzeia subterranean consumed in South-Eastern Nigeria. Journal of Agricultural Extension and Rural Development, 4, 57-62.

[3] Nwosu, J.N. (2013) Evaluation of the Proximate Composition and Antinutritional Properties of African Yam Bean (Sphenostylis sternocarpa) Using Malting Treatment. International Journal of Basic and Applied Sciences, 2, 157-169.

[4] Adebowale, Y.A. and Adebowale, K.O. (2007).Evaluation of Gelation Characteristics of Mucuna Bean Flour and Protein Isolate. Electronic Journal of Environmental, Agricultural and Food Chemistry, 6, 2243-2262.

[5] Adebowale, Y.A., Adeyemi, I.A. and Oshodi, A.A. (2005) Functional and Physicochemical Properties of Flours of Six 
Mucuna Species. African Journal of Biotechnology, 4, 1461-1468.

[6] Abbey, B.W. and Ibeh, G.O. (1987) Functional Properties of Raw and Heat Processed Brown Bean (Canavaliarosea DC) Flour. Journal of Food Science, 52, 406-408. http://dx.doi.org/10.1111/j.1365-2621.1987.tb06625.X

[7] Adeyeye, E.I. and Agesin, O.O. (2007) Dehulling the African Yam Bean (Sphenostylis stenocarpa Hochst. ex A. ich) Seeds: Any Nutritional Importance? Bangladesh Journal of Scientific \& Industrial Research, 42, 163-174. http://dx.doi.org/10.3329/bjsir.v42i2.469

[8] Ahenkora, K., Dadzie, M. and Osei-Bonsu, P. (1999) Composition and Functional Properties of Raw and Heat Processed Velvet Bean (Mucuna pruriens (L.) DC. var. utilis) Flours. International Journal of Food Science \& Technology, 34,131-135. http://dx.doi.org/10.1046/j.1365-2621.1999.00244.x

[9] Agbede, J.O. and Aletor, V.A. (2003) Comparative Evaluation of Weaning Foods from Gliricidia and Leucaena Leaf Protein Concentrates and Some Commercial Brands in Nigeria. Journal of the Science of Food and Agriculture, 84, 21-30. http://dx.doi.org/10.1002/jsfa.1563

[10] Balogun, A.M. and Fetuga, B.L. (1986) Chemical Composition of Some Underexploited Leguminous Crop Seeds in Nigeria. Journal of Agricultural and Food Chemistry, 34,189-192. http://dx.doi.org/10.1021/jf00068a008

[11] Azam-Ali, S.N., Sesay, A., Karikari, K.S., Massawe, F.J., Aguilar-Manjarrez, J., Bannayan, M. and Hampson, K.J. (2001) Assessing the Potential of an Underutilized Crop-A Case Study Using Bambara Groundnut. Experimental Agriculture, 37, 433-472. http://dx.doi.org/10.1017/S0014479701000412

[12] Mugendi, J.B.W., Njagi, E.N.M., Kuria, E.N., Mwasaru, M.A., Mureithi, J.G. and Apostolides, Z. (2010) Nutritional Quality and Physicochemical Properties of Mucuna Bean (Mucuna pruriens L.) Protein Isolates. International Food Research Journal, 17, 357-366.

[13] Gurumoorthi, P., Pugalenthi, M. and Janardhanan, K. (2003) Nutritional Potential of Five Accessions of a South Indian Tribal Pulse, Mucuna pruriens var. utilis II. Investigation on the Total Free Phenolics, Tannins, Trypsin and Chymotrypsin Inhibitors, Phytohaemagglutinins and In-Vitro Protein Digestibility. Tropical and Subtropical Agroecosystems, 1, 153-158.

[14] Adebowale, Y.A., Adeyemi, I.A. and Oshodi, A.A. (2005) Variability in the Physicochemical, Nutritional and Antinutritional Attributes of Six Mucuna Species. Food Chemistry, 89, 37-48. http://dx.doi.org/10.1016/j.foodchem.2004.01.084

[15] Aletor, V.A. and Aladetimi, O.O. (1989) Compositional Evaluation of Some Cowpea Varieties and Some Under-Utilized Edible Legumes in Nigeria. Nahrung, 33, 999-1007.

[16] Edem, D.O., Amugo, C.T. and Eka, O.U. (1990) Chemical Composition of Yam Bean (Sphenostylis sternocarpa) Trop. Science, 30, 59-63.

[17] Anderson, G.H. and Moore, S.E. (2004) Dietary Proteins in the Regulation of Food Intake and Body Weight in Humans. Journal of Nutrition, 134, 974-979.

[18] Arinathan, V., Mohan, V.R. and De-Britto, A.J. (2003) Chemical Composition of Certain Pulses in South India. International Journal of Food Sciences and Nutrition, 54, 209-217. http://dx.doi.org/10.1080/09637480120092026

[19] Campos-Vega, R., Reynoso-Camacho, R., Pedraza-Aboytes, G., Acosta-Gallegos, J.A., Guzman-Maldonado, S.H., Paredes-Lopez, O., Oomah, B.D. and Loarca-Piña, G. (2009) Chemical Composition and in Vitro Polysaccharide Fermentation of Different Beans (Phaseolus vulgaris L.). Journal of Food Science, 74, T59. http://dx.doi.org/10.1111/j.1750-3841.2009.01292.x

[20] Geil, P.B. and Anderson, J.W. (1994) Nutrition and Health Implications of Dry Beans: A Review. Journal of the American College of Nutrition, 13, 549-558. http://dx.doi.org/10.1080/07315724.1994.10718446

[21] Babar, V.S., Chavan, J.K. and Kadam, S.S. (1988) Effects of Heat Treatments and Germination on Trypsin Inhibitor Activity and Polyphenols in Jack Bean (Canavalia ensiformis L.DC). Plant Foods for Human Nutrition, 38, 319-324. http://dx.doi.org/10.1007/BF01091729

[22] Fasoyiro, S.B., Akande, S.R., Arowora, K.A., Sodeko, O.O., Sulaiman, P.O., Olapade, C.O. and Odiri, C.E. (2010) Physico-Chemical and Sensory Properties of Pigeon Pea (Cajanus cajan) Flours. African Journal of Food Science, 4, 120-126.

[23] Narayana, K. and Narasinga Rao, M.S. (1984) Effect of Partial Hydrolysis on Winged Bean Flours. Journal of Food Science, 49, 944-947. http://dx.doi.org/10.1111/j.1365-2621.1984.tb13247.x

[24] Kulkarni, K.D., Kulkarni, D.N. and Ingle, U.M. (1991) Sorghum Malt-Based Weaning Food Formulations: Preparation, Functional Properties and Nutritive Value. Food and Nutrition Bulletin, 13, 322-327.

[25] Takashi, S. and Seib, P.A. (1988) Paste and Gel Properties of Prime Corn and Wheat Starches with and without Native Lipids. Cereal Chemistry, 65, 474-483.

[26] Dipak, K. and Kumar, K.D. (1986) Functional Properties of Rapeseed Protein Products with Varying Phytic Contents. 
Journal of Agricultural and Food Chemistry, 34, 775-780. http://dx.doi.org/10.1021/jf00071a002

[27] AOAC (1984) Official Methods of Analysis. Association of Official Analytical Chemists, Washington DC.

[28] Dewar, J. (1999) Influence of Malting on Sorghum Protein Quality. A Report Submitted to CSIR Environmentek South Africa, 1-6.

[29] Onilude, A.A., Sanni, A.I. and Ighalo, M.I. (1999) Effect of Process Improvement on the Physico-Chemical Properties of Infant Weaning Food from Fermented Composite Blends of Cereal and Soybeans. Plant Foods for Human Nutrition, 54, 239-250. http://dx.doi.org/10.1023/A:1008105521196

[30] Hassan, A.K. and Arab-Abou, A.A. (1993) Comparison of Physical Chemical and Functional Properties of Moringa Peregrine and Soya Bean. Cereal Chemistry, 70, 619-626.

[31] Awoyinka, O.A. and Adebawo, O.O. (2008) Quality Assessment and Potential Utilization of High Amylolytic Nigerian Maize Cultivars. African Journal of Biotechnology, 7, 4331-4335.

[32] Ihekoronye, A.I. and Ngoddy, P.O. (1985) Integrated Food Science and Technology for the Tropics. University of Ibadan Press, Ibadan, 283.

[33] Chel-Guerrero, L., Perez-Flores, V., Bentacur-Ancona, D. and Davila-Ortiz, G. (2002) Functional Properties of Flours and Protein Isolates from Phaseolus lunatus and Canavalia ensiformis Seeds. Journal of Agricultural and Food Chemistry, 50, 584-591. http://dx.doi.org/10.1021/jf010778j

[34] Del Rio, D., Rodriguez-Mateos, A., Spencer, J.P.E., Tognolini, M., Borges, G. and Crozier, A. (2012) Dietary Polyphenolics in Human Health: Structures, Bioavailability, and Evidence of Protective Effects against Chronic Diseases. Antioxidants \& Redox Signaling, 12, 5-6.

[35] Minka, S.R. and Bruneteau, M. (2000) Partial Chemical Composition of Bambara Pea (Vigna subterranean L. Verde). Food Chemistry, 68, 273-276. http://dx.doi.org/10.1016/S0308-8146(99)00186-7

[36] Adu-Dapaah, H.K. and Sangwan, R.S. (2004) Improving Bambara Groundnut Productivity Using Gamma Irradiation and in Vitro Techniques. African Journal of Biotechnology, 3, 260-265. http://dx.doi.org/10.5897/AJB2004.000-2048

[37] Okpuzor, J., Ogbunugafor, H.A., Okafor, U. and Sofidiya, M.O. (2010) Identification of Protein Types in Bambara Nut Seeds: Perspectives for Dietary Protein Supply in Developing Countries. EXCLI Journal, 9, 17-28. 